\title{
Culture medium composition affects the gene expression pattern and in vitro development potential of bovine somatic cell nuclear transfer (SCNT) embryos
}

\author{
María E. Arias ${ }^{1}$, Pablo J. Ross ${ }^{2}$ And Ricardo N. Felmer ${ }^{1,3, *}$ \\ ' Laboratorio de Reproducción, Centro de Biotecnología de La Reproducción (BIOREN-CEBIOR), Facultad de Medicina, Universidad de La Frontera, Temuco, Chile. \\ 2 Department of Animal Science, University of California, Davis, USA. \\ 3 Facultad de Ciencias Agropecuarias y Forestales, Universidad de La Frontera, Temuco, Chile.
}

\begin{abstract}
Different culture systems have been studied that support development of somatic cell nuclear transfer (SCNT) embryos up to the blastocyst stage. However, the use of sequential and two-step culture systems has been less studied. The objective of the present study was to examine the developmental potential and quality of bovine SCNT embryos cultured in different two-step culture media based on KSOM, SOF and the macromolecules FBS and BSA (K-K/FBS, K-S/BSA and K-K/BSA, respectively). No differences were observed in the cleavage rate for any of the culture systems. However, there was a significant difference $(\mathrm{P}<0.01)$ in the rate of blastocyst development, with the K-K/ FBS culture system yielding a higher rate of blastocysts (28\%) compared to other treatments (18 and 15\%, for K-S/BSA and K-K/BSA, respectively). Although quality of embryos, as assessed by the total number of cells, was not different, the apoptosis index was significantly affected in the sequential culture system (K-S/BSA). Gene expression analysis showed alterations of DNMT1, IGF2, LIF, and PRDX6 genes in embryos cultured in K-S/FBS and of SOD2 in embryos cultured in K-K/BSA. In conclusion, we demonstrated that culture medium may affect not only the developmental potential of SCNT embryos but also, more importantly, the gene expression pattern and apoptotic index, presenting the possibility to manipulate the culture medium composition to modulate global gene expression and improve the overall efficiency of this technique.
\end{abstract}

Key words: Cattle, gene expression, KSOM, nuclear transfer embryos, SOF.

\section{INTRODUCTION}

Potential applications of animal cloning in agriculture, biotechnology, biomedicine and basic research (Cibelli et al., 1998, Wells et al., 1999, Keefer 2004) have increased interest in this technology for many researchers around the world. Nevertheless, despite the original success of cloning demonstrated by the generation of live offspring in different species (Cibelli et al., 1998, Wakayama et al., 1998, Baguisi et al., 1999, Polejaeva and Campbell 2000, Chesne et al., 2002, Shin et al., 2002, Galli et al., 2003, Zhou et al., 2003, Li et al., 2006), the efficiency of nuclear transfer is still far from optimum (Wilmut et al., 1997, Wakayama et al., 1998, Miyoshi et al., 2001). For instance, nuclear transfer success rates in cattle are around $11 \%$ with adult somatic cells (Kubota et al., 2000, Gibbons et al., 2002, Panarace et al., 2007), although in a few instances higher efficiencies have been described when blastomeres were used as nuclear donors (Peura and Trounson 1998). These data demonstrate that low efficiency is still a major drawback for widespread use of cloning technology.

Different factors have been recognized as contributing to the low efficiency of nuclear transfer, including aberrant reprogramming of the donor nucleus (Stice et al., 1998, Jouneau and Renard 2003), lack of cell cycle coordination between the recipient oocyte and the donor nucleus (Campbell et al., 1994, Gibbons et al., 2002), atypical oocyte activation (De La Fuente and King 1998, Alexander et al., 2006, Bhak et al., 2006) and in vitro culture conditions for the reconstructed embryos (Zakhartchenko et al., 1999, Mastromonaco et al., 2004). Improvement of culture conditions for in vitro fertilization (IVF) and somatic cell nuclear transfer (SCNT) embryos has been pursued for many years and a variety of culture media that support bovine embryo development have been developed, including synthetic oviductal fluid (SOF) (Tervit et al., 1972, Krisher et al., 1999), CR1aa medium (Rosenkrans and First 1994, Sims and First 1994), potassium simplex optimization medium (KSOM) (Liu and Foote 1995, Bhuiyan et al., 2004), Beltsville embryo culture medium (BECM) (Dobrinsky et al., 1996, Lim et al., 1999), G1/G2 medium (Krisher et al., 1999, Wang et al., 2011) and IVD101 (Abe and Hoshi 2003). Additionally, culture conditions based on defined components free of serum, BSA or cell constituents which may introduce uncharacterized factors into the culture and to some extent have been attributed to problems associated with large offspring syndrome (Young et al., 1998), are also being developed (Lim et al., 2007, Jang et al., 2011).

Culture conditions for bovine embryos can also involve the addition and subtraction of particular components of the basal medium in a second step of the culture (Gardner and Lane 1998, Lane et al., 2003) or the use of a different medium, as is the case in sequential and two step culture systems (Bavister 1995, Nedambale et al., 2004, Felmer et al., 2011). The main principle of these culture systems is that in vivo embryos move from the oviduct to the uterus; the secretions and gas atmosphere of these compartments differ in composition (Biggers et al., 2005, Hugentobler et al., 2008). Therefore, these culture systems are being developed in an effort to mimic the physiological conditions that embryos would have in vivo. 
Although a number of studies have compared the effects of these culture systems in IVF embryos, only few studies so far have evaluated these systems in SCNT embryos (Wang et al., 2011). This is particularly relevant for cloned bovine embryos, since the majority of the studies use only a single culture medium such as mSOF (Choi et al., 2002, Zhang et al., 2007).

In the present study we assessed the effects of three different two-step culture media on the in vitro development potential and quality of bovine SCNT embryos. Additionally, we studied the expression pattern of a number of developmentally important genes in pools of embryos cultured in these media, to establish differences in gene expression as result of the culture medium composition.

\section{MATERIAL AND METHODS}

Unless stated otherwise, all chemicals were purchased from Sigma Chemical (St Louis, MO, USA).

\section{Derivation of donor cells}

A tissue biopsy was obtained from the ear of a 6-yearold cow (Fries Hollands breed) and taken immediately to the laboratory in Dulbeccos's PBS medium (Gibco Life Technologies Corporation, Grand Island, NY, USA) containing $10 \%(\mathrm{v}: \mathrm{v})$ penicillin/streptomycin $(100,000 \mathrm{U} / \mathrm{ml}$ penicillin $\mathrm{G}, 100,000 \mu \mathrm{g} / \mathrm{ml}$ streptomycin) at $4{ }^{\circ} \mathrm{C}$. The tissue biopsy was cut into small pieces, and tissue explants were cultured in Dulbecco's Modified Eagle Medium (DMEM) (Gibco Life Technologies Corporation, Grand Island, NY, USA), supplemented with $10 \%$ inactivated fetal bovine serum (FBS) (Hyclone Laboratories, Inc., Logan, UT, USA) and 1\% (v:v) penicillin/streptomycin $(10000 \mathrm{U} / \mathrm{ml}$ penicillin $\mathrm{G}, 10000 \mu \mathrm{g} /$ $\mathrm{ml}$ streptomycin) at $38{ }^{\circ} \mathrm{C}$ in $35 \mathrm{~mm}$ tissue culture plates in a humidified atmosphere of $5 \% \mathrm{CO}_{2}$ in air. After 10 days in culture, explants were removed and cells harvested by trypsinization, counted, and seeded in $75 \mathrm{~cm}^{2}$ tissue culture flasks. When cells reached confluency they were collected by trypsinization and frozen until use in DMEM medium supplemented with $40 \%$ FBS and 10\% dimethyl sulfoxide (DMSO).

\section{Collection of ovaries, selection of oocytes and in vitro maturation}

Ovaries were collected from a local slaughterhouse (Frigorifico Temuco, Temuco, Chile). Cumulus-oocyte complexes (COCs) were aspirated from 2-7 mm follicles using an 18-gauge needle. Good quality oocytes surrounded by more than 6 compact layers of cumulus cells and displaying uniformly granulated cytoplasm were selected and matured in TCM-199 medium supplemented with $10 \%$ inactivated FBS and $6 \mu \mathrm{g} / \mathrm{mL} \mathrm{LH}$ (Sioux Biochemical, Inc., Sioux City, IA, USA), $6 \mu \mathrm{g} / \mathrm{mL}$ FSH (Bioniche Life Science Inc., Belleville, Ontario, Canada) and 1 $\mu \mathrm{g} / \mathrm{mL}$ estradiol, and then incubated for $17 \mathrm{~h}$ at $38.5^{\circ} \mathrm{C}$ in $5 \%$ $\mathrm{CO}_{2}$ and saturation humidity.

\section{Nuclear transfer procedure}

After $17 \mathrm{~h}$ of maturation, oocytes were stained with Hoechst 33342 and enucleated by aspiration of the MII plate using an inverted microscope (Nikon TS100, Nikon Instruments Inc., New York, NY, USA) and Narishige micromanipulators
(Narishige International, Inc., New York, NY, USA). Prior to nuclear transfer, nuclear donor cells (passage number $3-5)$, were grown to confluency for 5 days in order to induce quiescence. These cells were microsurgically placed into the perivitelline space evacuated during enucleation and cellcytoplast complexes were fused in sorbitol media with a single DC pulse of 150 volts $/ \mathrm{mm}$ and 15 seconds delivered by an Electrocell Manipulator 830 (BTX, Harvard Apparatus, Inc, Holliston, MA, USA). Activation was carried out with $5 \mu \mathrm{M}$ Ionomicin for 5 minutes followed by incubation in KSOM (EmbryoMax, Millipore, Billerica, MA, USA) + 0.4\% BSA medium containing $2 \mathrm{mM}$ DMAP for $4 \mathrm{~h}$.

\section{Embryo culture}

After activation, 730 NT units (10 biological replicates) were randomly distributed into $50 \mu \mathrm{l}$ drops of the following culture media: (1) $\mathrm{KSOM}+0.4 \%$ FAF-BSA for 3 days and then KSOM $+5 \%$ FBS to day 7, hereafter referred to as K-K/FBS; (2) KSOM $+0.1 \%$ BSA for 3 days and then SOF (custom made, Caisson Laboratories, Inc., UT, USA) $+0.8 \%$ BSA to day 7 (K-S/BSA), and (3) $\mathrm{KSOM}+0.4 \%$ BSA for 3 days and then $\mathrm{KSOM}+0.8 \%$ BSA to day 7 (K-K/BSA) (Table 1 ) and cultured at $38.5^{\circ} \mathrm{C}$ with a gas mixture of $5 \% \mathrm{CO}_{2}, 5 \% \mathrm{O}_{2}$ and $90 \% \mathrm{~N}_{2}$. These culture systems are based on different combinations of KSOM medium and have been previously evaluated by our group in bovine embryos generated by IVF (Felmer et al., 2011).

\section{Cell number count and TUNEL assay}

Cell number in day 7.5 expanded blastocysts (10 per treatment) was scored by incubating embryos in media (TCM-199) containing $10 \mu \mathrm{g} / \mathrm{mL}$ bisbenzimide in absolute ethanol at room temperature for $10 \mathrm{~min}$. Blastocysts were then treated in $50 \%(\mathrm{v} / \mathrm{v})$ glycerol, mounted onto a glass slide and visualized under an epifluorescent microscope coupled with a UV-2E/C DAPI filter. For TUNEL assay, blastocysts were permeabilized with $0.2 \%$ Triton for 5 minutes and fixed at room temperature $\left(\sim 24{ }^{\circ} \mathrm{C}\right)$ in $4 \%$ paraformaldehyde for $30 \mathrm{~min}$. Embryos were additionally permeabilized for 5 minutes with $0.1 \%$ sodium citrate containing $0.1 \%$ Triton, washed twice with PBS/ BSA and incubated with labelling reagent according to the manufacturer's instructions (Cell Death Detection kit, Roche Biochemical, Indianapolis, IN, USA). Finally, embryos were mounted onto a glass slide on drops of $10 \mu \mathrm{L}$ of antifade and examined under an epifluorescence microscope coupled with an EGFP filter as above. Positive controls for TUNEL were carried out by treating embryos with 15 U DNAse I for $15 \mathrm{~min}$ at $37{ }^{\circ} \mathrm{C}$ before the TUNEL assay, and negative controls by incubating embryos with the fluorescent labelling reagent in the absence of the terminal transferase dUTP enzyme.

\section{RNA extraction, reverse transcription and gene expression analysis}

Fifteen good quality expanded blastocysts divided into 3 pools per treatment (5 blastocysts/pool) were lysed in $20 \mu \mathrm{L}$ of extraction buffer (XB; Arcturus, Carlsbad, CA, USA) by incubation at $42{ }^{\circ} \mathrm{C}$ for 30 minutes followed by centrifugation at $3,000 \times \mathrm{g}$ for 2 minutes. RNA was kept frozen at $-80^{\circ} \mathrm{C}$ in the kit's extraction buffer until all samples were collected for analysis. Total RNA was extracted from each pool of embryos using the PicoPure RNA Isolation Kit (Arcturus, Carlsbad, 
TABLE 1

Composition of culture media used for SCNT embryo culture.

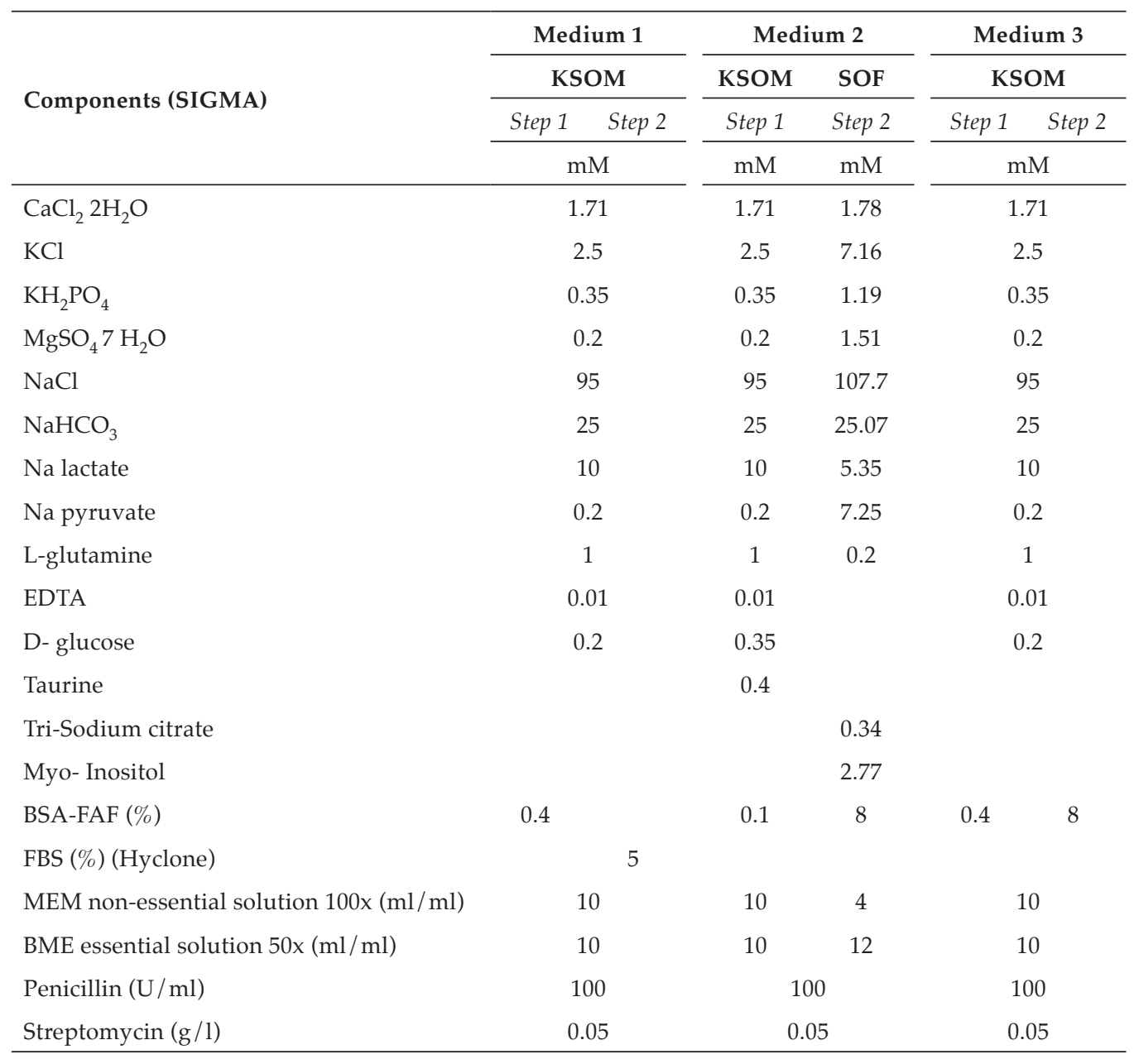

CA, USA) according to the manufacturer's instructions, and residual genomic DNA was removed by DNAse I digestion using 0.125 units final concentration of RNase-Free DNase Set (Qiagen, Valencia, CA, USA). Final RNA was eluted from the purification column using $11 \mu \mathrm{L}$ of the kit's elution buffer.

Reverse transcription was carried out with the RevertAid H Minus First Strand Kit (Thermo Scientific Inc., Pittsburgh, PA, USA), according to the manufacturer's instructions. Briefly, $10 \mu \mathrm{L}$ total RNA and $200 \mathrm{ng}$ of random hexamers were added to each $0.5 \mathrm{~mL}$ of RNase-free tube. The reaction tubes were incubated in a preheated PCR machine at $70{ }^{\circ} \mathrm{C}$ for 5 minutes and transferred to ice. After denaturation, the following reagents were added to each reaction tube: $4 \mu \mathrm{L}$ of $5 \mathrm{X}$ firststrand reaction buffer, $2 \mu \mathrm{L}$ of $10 \mathrm{mM}$ dNTPs, and $1 \mu \mathrm{L}$ of Riboblock. After gentle mixing, reaction tubes were incubated at $25{ }^{\circ} \mathrm{C}$ for 5 minutes. Then, $1 \mu \mathrm{L}$ of RevertAid ${ }^{\mathrm{TM}} \mathrm{M}$ MuLV RT was added and the mixture incubated at $42{ }^{\circ} \mathrm{C}$ for 60 minutes in a dry bath. The reaction was terminated by heating at $70{ }^{\circ} \mathrm{C}$ for 10 minutes and then chilled on ice. This first-strand cDNA was diluted 5 times and used for real time experiments.

Quantification of a panel of 19 developmentally-important genes (primer sequences published in Felmer et al. (2011) was carried out by RT-qPCR using Brilliant II SYBR Green QPCR Master Mix (Agilent Technologies, Palo Alto, CA, USA) in a thermocycler MX3000P (Agilent Technologies, Palo Alto, CA, USA). All PCR reactions were performed in duplicate wells in a final volume of $20 \mu \mathrm{L}$ containing $4 \mu \mathrm{L}$ of diluted cDNA, 10 $\mu \mathrm{L}$ of Master mix, $4 \mu \mathrm{L}$ of primer mix (300 nM final), and $2 \mu \mathrm{L}$ of PCR-grade water. The PCR program consisted of an initial incubation at $95{ }^{\circ} \mathrm{C}$ for 5 minutes to activate the Taq DNA polymerase, followed by 40 cycles of template denaturation at $95{ }^{\circ} \mathrm{C}$ for 20 seconds, a primer annealing step at $58{ }^{\circ} \mathrm{C}$ for 20 seconds (same annealing for all primers), and an extension step at $72{ }^{\circ} \mathrm{C}$ for 20 seconds. A control for removal of genomic DNA after DNAse treatment (-RT) was performed with primers for $A C T B$ and negative control tubes without cDNA template were included in each assay. At the end of the PCR reaction, melting curve analyses were performed for all genes, and the specificity as well as integrity of the PCR products was confirmed by the presence of a single peak (data not shown). PCR efficiencies (E) were estimated using relative standard curves derived from a pooled cDNA mixture from in vitro produced embryos (a 10-fold dilution series with five measuring points). These values were determined by the slopes of the curves according to the equation $\mathrm{E}=10^{(-1 / \text { slope })}$ established by Pfaffl (2001).

The comparative $C t$ method was used to quantify of mRNA expression levels using the amplification efficiency of each 
gene as a correction factor (Livak and Schmittgen 2001). For normalization we used the geometric average of the $B A X$, GAPDH and YWHAZ reference genes, after analysis with the geNorm Visual Basic Application program for Microsoft Excel as described by Vandesompele et al. (2002), confirming their stability under our laboratory conditions (data not shown). To measure the differences in expression between the different culture media, we used the pairwise fixed reallocation randomization test in the Relative Expression Software Tool (REST; V2.0.7, Copyright 2008, Corbett Research Pty. Limited, Munich, Germany) (Pfaffl et al., 2002).

\section{Statistical analysis}

Data analysis for embryo development and cell count was carried out by descriptive statistics based on the mean and standard error calculated for each of the variables, using Statgraphics Plus 5.1 software (StatPoint Technologies Inc., Warrenton, VA, USA). One-way ANOVA was used to test for statistically significant differences among treatments for cleavage, blastocyst rate and cell counting after arcsine transformation of the proportional data. Post hoc analysis to identify differences between groups was carried out using the Scheffé test. An error probability of $\mathrm{P}<0.05$ was considered significant.

\section{RESULTS}

Effect of culture medium on the in vitro developmental competence of bovine SCNT embryos.

The result of nine replicates with a total of 730 NT embryos randomly distributed among the three different culture media showed no differences in the cleavage rate at $72 \mathrm{~h}$ of culture $(75,77$ and $74 \%$ for K-K/FBS, K-S/BSA and K-K/BSA, respectively) (Table 2). However, significant differences in the rate of blastocysts were observed on day 7 of culture $(p<0.001)$. A greater proportion of embryos reached the blastocyst stage when they were cultured in K-K/FBS (28\%) medium compared to K-S/BSA (18\%) and K-K/BSA (15\%) (Table 2 and Fig. 1). Hatching rates were higher in K-K/FBS $(71 \%)$ and K-S/BSA (52\%) compared to K-K/BSA (42\%) (Table 2).

Effect of culture medium on the total number of cells and frequency of apoptotic nuclei in bovine SCNT embryos.

Total number of cells and apoptosis index were assessed to determine any effect of the culture medium on embryo quality. As observed in Table 3, the total number of cells was not different between culture media $(128.0 \pm 4.4,119.7 \pm 4.6$ and 124.6 \pm 3.0 for K-K/FBS, K-S/BSA, and K-K/BSA, respectively)
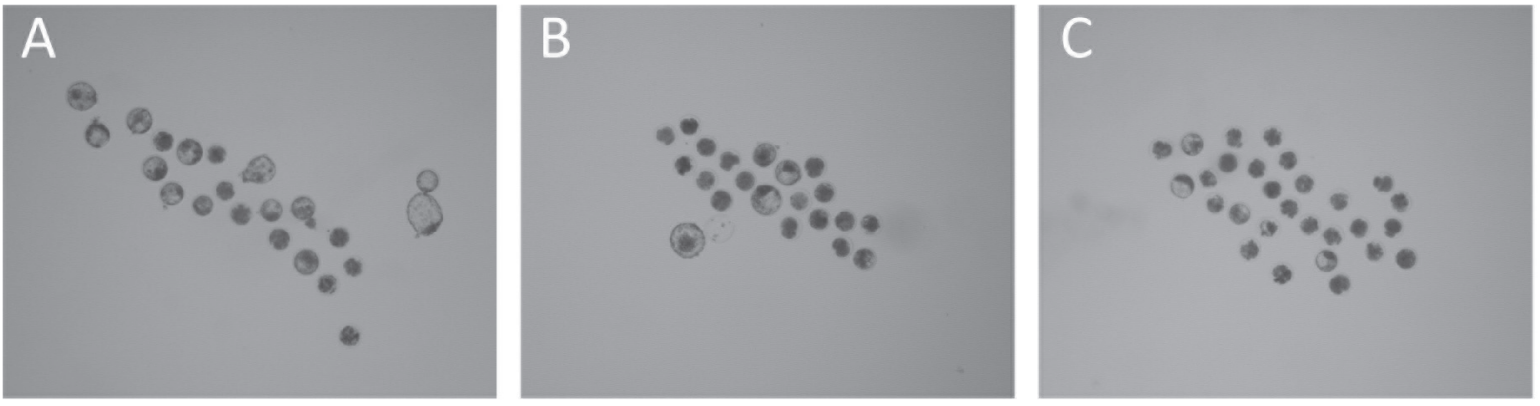

Figure 1. In vitro-produced bovine SCNT embryos from K-K/FBS (A), K-S/BSA (B), and K-K/BSA (C) culture systems on day 7, magnification: $40 \mathrm{x}$.

TABLE 2

Effect of different culture media on the in vitro development of bovine SCNT embryos

\begin{tabular}{|c|c|c|c|c|c|}
\hline \multicolumn{2}{|c|}{ Two steps in vitro culture system } & \multirow{2}{*}{$\begin{array}{c}\text { Oocytes } \\
n\end{array}$} & \multirow{2}{*}{$\begin{array}{c}\text { Cleavage } \\
n(\%)\end{array}$} & \multirow{2}{*}{$\begin{array}{c}\text { Total Blastocysts } \\
n(\%)\end{array}$} & \multirow{2}{*}{$\begin{array}{l}\text { Hatching Blastocysts } \\
\qquad(\%)^{*}\end{array}$} \\
\hline $\begin{array}{l}\text { Step one } \\
(72 \mathrm{~h})\end{array}$ & $\begin{array}{l}\text { Step two } \\
(96 \mathrm{~h})\end{array}$ & & & & \\
\hline $\begin{array}{c}\text { KSOM } \\
0.4 \% \text { BSA }\end{array}$ & $\begin{array}{c}\text { KSOM } \\
5 \% \text { FBS }\end{array}$ & 245 & $183(75)$ & $68(28)^{a}$ & $48(71)^{\mathrm{a}}$ \\
\hline $\begin{array}{c}\text { KSOM } \\
0.1 \% \text { BSA }\end{array}$ & $\begin{array}{c}\text { SOF } \\
0.8 \% \text { BSA }\end{array}$ & 247 & $191(77)$ & $44(18)^{\mathrm{b}}$ & $23(52)^{a, b}$ \\
\hline $\begin{array}{c}\text { KSOM } \\
0.4 \% \text { BSA }\end{array}$ & $\begin{array}{c}\text { KSOM } \\
0.8 \% \text { BSA }\end{array}$ & 238 & $177(74)$ & $36(15)^{\mathrm{b}}$ & $15(42)^{b}$ \\
\hline
\end{tabular}

Cleavage and blastocyst rates were registered at 72 and $168 \mathrm{~h}$, respectively (9 replicates). *Percentage is based on the total number of blastocysts. Data followed by different letters in the same column are statistically different $(\mathrm{P}<0.01)$. 


\section{TABLE 3}

Effect of different culture media on the quality and apoptosis index of bovine SCNT embryos

\begin{tabular}{|c|c|c|c|c|c|}
\hline & & \multicolumn{4}{|c|}{$\begin{array}{c}\text { Cell number } \\
(\text { mean } \pm \text { SEM) }\end{array}$} \\
\hline \multicolumn{2}{|c|}{ Culture treatment } & Number of embryos & Total cells & Apoptotic blastomeres & Apoptotis index $(\%)$ \\
\hline $\begin{array}{c}\text { KSOM } \\
0.4 \% \text { BSA }\end{array}$ & $\begin{array}{l}\text { KSOM } \\
5 \% \text { FBS }\end{array}$ & 10 & $128.0 \pm 4.4^{\mathrm{a}}$ & $4.5 \pm 0.3^{\mathrm{a}}$ & $3.52 \pm 0.22^{\mathrm{a}}$ \\
\hline $\begin{array}{c}\text { KSOM } \\
0.1 \% \text { BSA }\end{array}$ & $\begin{array}{c}\text { SOF } \\
0.8 \% \text { BSA }\end{array}$ & 10 & $119.7 \pm 4.6^{\mathrm{a}}$ & $6.3 \pm 0.2^{b}$ & $5.35 \pm 0.30^{b}$ \\
\hline $\begin{array}{c}\text { KSOM } \\
0.4 \% \text { BSA }\end{array}$ & $\begin{array}{c}\text { KSOM } \\
0.8 \% \text { BSA }\end{array}$ & 10 & $124.6 \pm 3.0^{\mathrm{a}}$ & $4.8 \pm 0.2^{\mathrm{a}}$ & $3.88 \pm 0.22^{\mathrm{a}}$ \\
\hline
\end{tabular}

Cell count and apoptosis index was carried out on day 7.5 expanded blastocysts. Data followed by different letters in the same column are statistically different $(p<0.001)$.

(Table 3). However, a higher proportion $(\mathrm{P}<0.01)$ of apoptotic to total cell ratio was observed in embryos cultured in K-S/ BSA (5.35 \pm 0.30$)$ compared to embryos cultured in K-K/FBS $(3.52 \pm 0.22)$ and K-K/BSA $(3.88 \pm 0.22)$ (Table 3$)$.

Effect of culture medium on the gene expression profile of bovine SCNT embryos.

Gene expression analysis carried out on day-7 expanded blastocysts showed an increase in the expression level of LIF $(\mathrm{p}<0.05)$ and a decrease in the expression levels of DNMT1 $(\mathrm{p}<0.05)$, IGF2 $(\mathrm{p}<0.05)$, and PRDX6 $(\mathrm{p}<0.05)$ in embryos cultured in K-S/BSA compared to embryos cultured in K-K/ FBS. On the contrary, in embryos cultured in K-K/BSA only one gene was affected (SOD2, $\mathrm{p}<0.05)$ compared to embryos cultured in K-K/FBS (Table 4).

\section{DISCUSSION}

A number of different culture media have been extensively evaluated in an effort to improve the quality of embryos produced in vitro and to mimic the physiological conditions that embryos would have in vivo. Most of this work has been carried out in embryos produced by IVF and only a few studies have focused on the evaluation of different culture media for embryos produced by SCNT, presumably due to the early assumption that both embryo production methods would behave similarly under the same culture conditions and because of the extra technical requirements involved in the generation of SCNT embryos. However, previous studies in mice demonstrated that SCNT embryos had better developmental potential when cultured in somatic cell culture medium $(\mathrm{MEM} \alpha)$ rather than in IVF-optimized KSOM medium (Gao et al., 2004). Similarly, in cattle Mastromonaco et al. (2004) observed that replacement of serum with BSA in the maturation medium had no effect on the developmental potential of embryos generated by IVF. However, a lower blastocyst rate was observed in SCNT embryos, demonstrating different culture media requirements for embryos produced by IVF and SCNT.

In the present study, presence of serum at later stages of development in the K-K/FBS culture system increased the development rate to the blastocyst stage but replacement of serum by BSA either in K-K/BSA or K-S/ BSA culture systems did not have the same stimulatory effect on SCNT embryos. This result is consistent with a number of previous studies in IVF embryos that have demonstrated that presence of serum during the late culture period increases the rate of morulas and blastocysts, regardless of the culture medium composition (Lim et al., 1994, Dobrinsky et al., 1996, Yoshioka et al., 1997, Lonergan et al., 1999). However, in other studies in IVF embryos cultured in modified SOFaa, presence of serum or BSA had no effect on the development of embryos cultured up to day 9 (Mastromonaco et al., 2004). A similar result was observed recently by our group in bovine embryos generated by IVF and cultured in KSOM medium either in the presence of serum (K-K/FBS) or in its absence (K-K/BSA) (Felmer et al., 2011). However, in the present study the lack of serum in SCNT embryos dramatically decreased the developmental potential of embryos in K-K/BSA and K-S/BSA culture systems, confirming the different preferences of IVF and SCNT embryos for varying culture conditions. Furthermore, lack of serum also affected the kinetics of embryos, with embryos cultured in K-K/BSA showing the lowest number of expanded and hatching blastocysts on day 7 .

Addition of serum to the culture medium has been previously observed to accelerate the developmental kinetics of embryos, increasing the numbers of blastocysts at early stages (day 6) and hatching and hatched blastocysts on days 8 and 9, respectively (Wang et al., 1997, Gomez and Diez 2000, Holm et al., 2002). This accelerated development has been suggested to induce a number of unfavorable consequences to the embryo, including impaired morula compaction, premature blastulation and an altered gene expression pattern (Holm et al., 2002, Rizos et al., 2003, Wrenzycki and Niemann 2003). However, the late inclusion of serum in the culture system appears to have less negative effects. In fact, previous studies in embryos have demonstrated a biphasic effect of serum inhibiting the early stages of embryo development and improving the development to morulas and blastocysts regardless of the culture composition (Yoshioka et al., 1997, Thompson et al., 1998, Lonergan et al., 1999). Here, we observed that addition of serum to a two-step culture system (K-K/FBS), not only improved the development rate and produced a greater number of blastocysts and hatching blastocysts, but also improved the quality of these embryos, without greatly affecting the gene expression patterns compared to culture systems without serum. 
TABLE 4

Analysis of gene expression in day 7 expanded SCNT blastocysts cultured in different media

\begin{tabular}{|c|c|c|c|c|c|c|}
\hline \multicolumn{7}{|c|}{ CULTURE SYSTEMS COMPARED } \\
\hline & \multicolumn{3}{|c|}{ K-K/FBS - K-S/BSA } & \multicolumn{3}{|c|}{ K-K/FBS - K-K/BSA } \\
\hline Gene & Expression & 95\% C.I. & $\mathrm{P}(\mathrm{H} 1)$ & Expression & 95\% C.I. & $\mathrm{P}(\mathrm{H} 1)$ \\
\hline$B A X$ & 2.108 & \multicolumn{2}{|c|}{ Reference gene } & 1.168 & \multicolumn{2}{|c|}{ Reference gene } \\
\hline$C A T$ & 1.006 & $0.507-1.742$ & 0.974 & 1.298 & $0.891-1.650$ & 0.107 \\
\hline DNMT1 & 0.290 & $0.246-0.351$ & 0.017 (down) & 0.854 & $0.556-1.160$ & 0.550 \\
\hline FGF4 & 5.119 & $2.260-10.112$ & 0.073 & 1.422 & $0.841-2.443$ & 0.162 \\
\hline GAPDH & 0.374 & \multicolumn{2}{|c|}{ Reference gene } & 0.962 & \multicolumn{2}{|c|}{ Reference gene } \\
\hline GLUT1 & 1.833 & $1.485-2.432$ & 0.063 & 1.242 & $0.974-1.701$ & 0.206 \\
\hline GPX1 & 4.854 & $2.770-8.611$ & 0.051 & 1.590 & $0.675-3.286$ & 0.209 \\
\hline GSS & 0.983 & $0.490-2.103$ & 0.823 & 1.360 & $0.805-2.540$ & 0.393 \\
\hline HDAC1 & 0.628 & $0.298-1.042$ & 0.221 & 1.183 & $0.845-1.493$ & 0.099 \\
\hline HDAC2 & 1.492 & $0.995-2.918$ & 0.170 & 0.988 & $0.837-1.204$ & 0.828 \\
\hline$H D A C 3$ & 0.726 & $0.431-1.510$ & 0.211 & 0.849 & $0.517-1.365$ & 0.471 \\
\hline IFNT & 0.484 & $0.121-1.294$ & 0.518 & 1.511 & $0.335-5.264$ & 0.418 \\
\hline IGF2 & 0.217 & $0.088-0.352$ & 0.028 (down) & 1.106 & $0.725-1.529$ & 0.580 \\
\hline LIF & 7.036 & $2.744-14.064$ & 0.029 (up) & 2.046 & $0.698-5.496$ & 0.118 \\
\hline PRDX6 & 0.339 & $0.184-0.659$ & 0.017 (down) & 1.152 & $0.658-1.664$ & 0.498 \\
\hline SDHA & 1.437 & $0.738-2.477$ & 0.269 & 1.317 & $1.008-1.814$ & 0.099 \\
\hline SOD1 & 0.577 & $0.296-1.307$ & 0.138 & 1.074 & $0.598-2.015$ & 0.642 \\
\hline SOD2 & 3.777 & $1.688-9.726$ & 0.074 & 1.730 & $1.104-2.880$ & 0.040 (up) \\
\hline YWHAZ & 1.267 & \multicolumn{2}{|c|}{ Reference gene } & 0.890 & \multicolumn{2}{|c|}{ Reference gene } \\
\hline
\end{tabular}

Gene expression data analysis was carried out by comparing all culture systems relative to K-K/FBS. Reference genes (BAX, GAPDH and $Y W H A Z$ ) were selected based on pair-wise analysis of their expression stability by the GeNorm program. Expression: Expression ratios obtained by using randomization and boot strapping techniques included in the REST program; $95 \% \mathrm{Cl}$ : range of confidence interval $(95 \%)$ for the expression ratios; $\mathrm{P}(\mathrm{H} 1)$ : probability of the alternate hypothesis that the difference between the sample and control groups is due only to chance. Shown in bold are the genes that were found up or down-regulated in the culture systems evaluated relative to K-K/FBS.

Due to suboptimal culture conditions and the supplementation of culture media with different macromolecules and growth factors, embryos produced in vitro show lower number of cells and a higher apoptotic index compared to embryos produced in vivo (Kamjoo et al., 2002, Koo et al., 2002). The quality of embryos in the present study as assessed by the total number of cells was not different in any of the culture media evaluated and was similar in quality to previously described embryos produced in vivo or by IVF (Koo et al., 2002). However, differences were observed in the apoptotic index, with sequential culture medium K-S/BSA showing the highest number of apoptotic cells. This result suggests that two-step culture media K-K/FBS and K-K/BSA better support culture conditions for bovine SCNT embryos than the sequential culture medium (K-S/BSA). In this latter case, the transition from one medium to another with different composition might be more detrimental for the quality of the embryos, increasing the number of apoptotic nuclei. It has been previously suggested that a higher apoptosis rate might contribute towards embryo mortality or anomalies in the fetus that could trigger early abortions (Brill et al., 1999). Culture conditions minimizing this effect should therefore be preferred in order to generate better quality embryos. Interestingly, although we observed a similar effect in a previous study comparing these culture media in embryos generated by IVF (Felmer et al., 2011), different results have been described recently by Xiong et al. (2012), comparing the most common single-step culture medium, mSOFaa, and the sequential culture medium G1.5/G2.5. These authors observed a higher apoptotic index in SCNT embryos derived from a single step culture medium (SOFaa) than in a sequential culture medium (G1.5/G2.5). In embryos generated by IVF, however, a much higher apoptotic index was observed when embryos were cultured in G1.5/G2.5 relative to SOFaa (Xiong et al., 2012).

Previous comparative studies in IVF embryos have evaluated the effects of culture media on the in vitro development potential and quality of embryos as assessed by the total number of cells and, to a lesser extent, their distribution in the different compartments of the embryo. Considering that these endpoints may not necessarily reflect the actual competence of a culture system, we sought to assess the effect of these culture media on the gene expression pattern of 19 developmentally important genes in order to establish if two-step culture media have an impact on the 
expression of these genes. Our results confirmed a differential expression pattern of embryos cultured in these culture media. We observed an increase in the expression level of LIF and a decrease of DNMT1, IGF2, and PRDX6 in embryos cultured in sequential culture medium K-S/BSA compared to embryos cultured in K-K/FBS. Contrarily, in embryos cultured in the two-step culture medium K-K/BSA only one gene was found altered (SOD2) compared to K-K/FBS.

Leukemia inhibitory factor (LIF) plays a crucial role during early differentiation and implantation of embryos. In cattle, great expression of this gene and its receptor were previously observed in IVF versus in vivo-produced blastocysts, suggesting that this condition could lead to impaired development of the inner cell mass and trophectoderm compartments of embryos (Eckert and Niemann 1998). A similar result was also observed by Rizos et al. (2002), who detected expression of LIF only in IVF blastocysts, regardless of the in vitro culture medium used compared to embryos produced in vivo. These data suggest that the overexpression of LIF observed in our study in SCNT embryos cultured in the K-S/BSA medium could compromise the early differentiation of blastocysts cultured in this medium and subsequent postimplantation development, because down-regulation of this gene is required to allow appropriate differentiation of embryo cell compartments (van Soom et al., 1997).

Insulin-like growth factor 2 (IGF2), is an imprinted gene encoding a growth factor involved in fetal and placental development and therefore essential for normal development (Perecin et al., 2009). This gene appears to be biallelically transcribed up to the morula stage but the maternal allele is silenced at the blastocyst stage (Ohno et al., 2001). Previous studies in bovine embryos demonstrated that blastocysts produced by IVF have lower expression of IGF2 compared to those produced in vivo, reflecting a reduction in the viability of embryos produced in vitro (Bertolini et al., 2002). In SCNT embryos, Perecin et al. (2009) also observed that embryos at later stages of development (33-36 days) had lower expression of IGF2 compared to in vivo and IVF-produced embryos. It was suggested in this case that abnormal expression of imprinted genes is one of the causes of the low efficiency in the cloning process (Perecin et al., 2009). However, some contradictory results have also been observed with this gene. For instance, Han et al. (2003) described that bovine SCNT blastocysts have increased expression of IGF2 compared to IVF blastocysts. Furthermore, these authors demonstrated that IGF2 expression was greater in the SCNT embryos cultured in serum containing medium, suggesting that the presence of exogenous proteins in the culture medium affected critical development points (Pandey et al., 2010). In agreement with some previous findings, the low expression of IGF2 observed in our bovine SCNT embryos cultured in K-S/BSA medium could be responsible for the low pre-implantation development observed presently. Culture conditions of embryos, particularly the presence of serum in the culture medium, could also affect the expression of this gene, as observed previously by Pandey et al. (2010). In our study however, we did not observe the same effect because no differences were found in embryos cultured in the presence of serum (K-K/FBS) or in its absence (K-K/BSA), suggesting that other factors could be responsible for this effect (e.g. culture medium composition).

Low expression of IGF2 could also affect post-implantation potential or normal growth of the offspring. Previous studies in the mouse model have demonstrated that low expression of this gene is associated with growth retardation (DeChiara et al., 1990, Eggenschwiler et al., 1997) and therefore this gene could be considered a good marker for embryo quality.

DNA methyltransferase 1 (DNMT1) is responsible for maintenance of methylation patterns of hemimethylated $\mathrm{CpG}$ dinucleotides after DNA replication (Bestor 1992). DNMT1 knockout mice show abnormal imprinting, reduced levels of DNA methylation and embryo lethality, confirming its essential role during early development (Li et al., 1992, Li et al., 1993, Robertson et al., 1999). In our study, the low expression of DNMT1 in SCNT embryos cultured in K-S/ BSA medium could also explain the lower development rate observed in these embryos. In a different study, expression level of DNMT1 was found to be significantly reduced in SCNT embryos compared to embryos generated by IVF. However, low levels of DNMT1 were also found in in vivoderived embryos, suggesting that the method of embryo production has a greater effect on the expression of this gene than the protocols used for the generation of SCNT embryos (Wrenzycki et al., 2001). On the other hand, Amarnath et al. (2007) found no differences in the expression pattern of DNMT1 between IVF and SCNT embryos using cumulus cells and skin fibroblasts as nuclear donors (Amarnath et al., 2007). In this case, the differences could be attributed to the experimental procedure employed and selection of reference genes for normalization of gene expression data, which were different in the two studies.

Peroxiredoxin 6 (PRDX6) is a bifunctional enzyme with peroxidase and phospholipase A2 activity (Fisher 2011). In cattle, PRDX6 transcripts have been identified in varying amounts in oocytes and embryos produced in vitro (Leyens et al., 2004). Studies in genetically engineered mice and cells indicate that inhibition of this gene increases susceptibility to oxidative damage and leads to cell death (Pak et al., 2002), while its overexpression reduces the levels of $\mathrm{H}_{2} \mathrm{O}_{2}$ (Phelan et al., 2003) and provides protection against oxidative stress and apoptosis (Manevich et al., 2002). Based on these data, the low expression of PRDX6 in our SCNT embryos cultured in K-S/ BSA could also be negatively compromising the development potential of these embryos.

Reactive oxygen species (ROS) are indicated as being one of the main factors responsible for the low production and poor quality of embryos produced in vitro (Takahashi et al., 2000). It has also been observed that physiological levels of ROS are necessary for normal regulation of cell growth and development (Hancock et al., 2001). SOD2 (Manganese superoxide dismutase, located in the mitochondria) is an important enzyme involved in the protection against ROS. Different studies in bovine IVF embryos have associated high levels of expression of SOD2 with better quality of embryos (Rizos et al., 2002, Lonergan et al., 2003). Recently in cattle, Amarnath et al (2007) suggested that this observation might not apply to SCNT embryos because they showed greater expression of SOD2 compared to IVF embryos despite the acknowledged poor in vivo development potential of SCNT embryos (Amarnath et al., 2007). However, contradictory results have been also observed more recently by Kim et al. (2012), who described no differences in the expression levels of SOD2 between bovine SCNT and IVF embryos, although a higher expression level of SOD2 was described in SCNT embryos activated by a repeated ionomycin treatment (Kim et 
al., 2012). In our study, an increased expression level of SOD2 was found in SCNT embryos cultured in K-K/BSA medium. In this case, despite the lower developmental potential observed with this medium we suggest that embryos generated by this culture medium are of good quality, which is corroborated by the morphological, cellular and apoptosis assessments that showed similar quality to those embryos cultured in the presence of serum (K-K/FBS).

In conclusion, the results of the present study show that the use of KSOM medium supplemented with 5\% FBS after 3 days of culture can improve the blastocyst formation rate of SCNT embryos and reduce the incidence of apoptosis compared to other two-step culture media supplemented with BSA. Furthermore, the differential expression pattern observed in SCNT embryos cultured in different culture media confirm the feasibility of generating higher quality embryos through changes in culture medium composition, a factor that could be manipulated by the use of chemically-defined media.

\section{ACKNOWLEDGEMENTS}

The provision of ovaries by our local slaughterhouse (Frigorifico Temuco, Temuco, Chile) and funding support from CONICYT-Chile, grant FONDECYT 1080216 are gratefully acknowledged.

\section{REFERENCES}

ABE H, HOSHI H (2003) Evaluation of bovine embryos produced in high performance serum-free media. J Reprod Dev 49: 193-202.

ALEXANDER B, COPPOLA G, DI BERARDINO D, RHO GJ, ST JOHN E, BETTS DH, KING WA (2006) The effect of 6-dimethylaminopurine (6-DMAP) and cycloheximide (CHX) on the development and chromosomal complement of sheep parthenogenetic and nuclear transfer embryos. Mol Reprod Dev 73: 20-30.

AMARNATH D, LI X, KATO Y, TSUNODA Y (2007) Gene expression in individual bovine somatic cell cloned embryos at the 8-cell and blastocyst stages of preimplantation development. J Reprod Dev 53: 1247-1263.

BAGUISI A, BEHBOODI E, MELICAN DT, POLLOCK JS, DESTREMPES MM, CAMMUSO C, WILLIAMS JL, NIMS SD, PORTER CA, MIDURA P, PALACIOS MJ, AYRES SL, DENNISTON RS, HAYES ML, ZIOMEK CA, MEADE HM, GODKE RA, GAVIN WG, OVERSTROM EW, ECHELARD Y (1999) Production of goats by somatic cell nuclear transfer. Nat Biotechnol 17: 456-461.

BAVISTER BD (1995) Culture of preimplantation embryos: facts and artifacts. Hum Reprod Update 1: 91-148.

BERTOLINI M, BEAM SW, SHIM H, BERTOLINI LR, MOYER AL, FAMULA TR, ANDERSON GB (2002) Growth, development, and gene expression by in vivo -and in vitro-produced day 7 and 16 bovine embryos. Mol Reprod Dev 63: 318-328.

BESTOR TH (1992) Activation of mammalian DNA methyltransferase by cleavage of a Zn binding regulatory domain. EMBO J 11: 2611-2617.

BHAK JS, LEE SL, OCK SA, MOHANA KUMAR B, CHOE SY, RHO GJ (2006) Developmental rate and ploidy of embryos produced by nuclear transfer with different activation treatments in cattle. Anim Reprod Sci 92: $37-49$.

BHUIYAN MM, CHO JK, JANG G, PARK ES, KANG SK, LEE BC, HWANG WS (2004) Effect of protein supplementation in potassium simplex optimization medium on preimplantation development of bovine nontransgenic and transgenic cloned embryos. Theriogenology 62: 1403-1416.

BIGGERS JD, MCGINNIS LK, LAWITTS JA (2005) One-step versus two-step culture of mouse preimplantation embryos: is there a difference? Hum Reprod 20: 3376-3384.

BRILL A, TORCHINSKY A, CARP H, TODER V (1999) The role of apoptosis in normal and abnormal embryonic development. J Assist Reprod Genet 16: $512-519$.

CAMPBELL KH, LOI P, CAPPAI P, WILMUT I (1994) Improved development to blastocyst of ovine nuclear transfer embryos reconstructed during the presumptive S-phase of enucleated activated oocytes. Biol Reprod 50: 1385-1393.

CIBELLI JB, STICE SL, GOLUEKE PJ, KANE JJ, JERRY J, BLACKWELL C, PONCE DE LEON FA, ROBL JM (1998) Cloned transgenic calves produced from nonquiescent fetal fibroblasts. Science 280: 1256-1258.

CHESNE P, ADENOT PG, VIGLIETTA C, BARATTE M, BOULANGER L, RENARD JP (2002) Cloned rabbits produced by nuclear transfer from adult somatic cells. Nat Biotechnol 20: 366-369.

CHOI YH, LEE BC, LIM JM, KANG SK, HWANG WS (2002) Optimization of culture medium for cloned bovine embryos and its influence on pregnancy and delivery outcome. Theriogenology 58: 1187-1197.

DE LA FUENTE R, KING WA (1998) Developmental consequences of karyokinesis without cytokinesis during the first mitotic cell cycle of bovine parthenotes. Biol Reprod 58: 952-962.

DECHIARA TM, EFSTRATIADIS A, ROBERTSON EJ (1990) A growthdeficiency phenotype in heterozygous mice carrying an insulin-like growth factor II gene disrupted by targeting. Nature 345: 78-80.

DOBRINSKY JR, JOHNSON LA, RATH D (1996) Development of a culture medium (BECM-3) for porcine embryos: effects of bovine serum albumin and fetal bovine serum on embryo development. Biol Reprod 55: 1069-1074.

ECKERT J, NIEMANN H (1998) mRNA expression of leukaemia inhibitory factor (LIF) and its receptor subunits glycoprotein 130 and LIF-receptorbeta in bovine embryos derived in vitro or in vivo. Mol Hum Reprod 4: 957-965.

EGGENSCHWILER J, LUDWIG T, FISHER P, LEIGHTON PA, TILGHMAN SM, EFSTRATIADIS A (1997) Mouse mutant embryos overexpressing IGF-II exhibit phenotypic features of the Beckwith-Wiedemann and Simpson-Golabi-Behmel syndromes. Genes Dev 11: 3128-3142.

FELMER RN, ARIAS ME, MUNOZ GA, RIO JH (2011) Effect of different sequential and two-step culture systems on the development, quality, and RNA expression profile of bovine blastocysts produced in vitro. Mol Reprod Dev 78: 403-414.

FISHER AB (2011) Peroxiredoxin 6: a bifunctional enzyme with glutathione peroxidase and phospholipase A(2) activities. Antioxid Redox Signal 15: 831-844.

GALLI C, LAGUTINA I, LAZZARI G (2003) Introduction to cloning by nuclear transplantation. Cloning Stem Cells 5: 223-232.

GAO S, CZIRR E, CHUNG YG, HAN Z, LATHAM KE (2004) Genetic variation in oocyte phenotype revealed through parthenogenesis and cloning: correlation with differences in pronuclear epigenetic modification. Biol Reprod 70: 1162-1170.

GARDNER DK, LANE M (1998) Culture of viable human blastocysts in defined sequential serum-free media. Hum Reprod 13 Suppl 3: 148-159; discussion 160 .

GIBBONS I, ARAT S, RZUCIDLO J, MIYOSHI K, WALTENBURG R, RESPESS D, VENABLE A, STICE S (2002) Enhanced survivability of cloned calves derived from roscovitine-treated adult somatic cells. Biol Reprod 66: 895-900.

GOMEZ E, DIEZ C (2000) Effects of glucose and protein sources on bovine embryo development in vitro. Anim Reprod Sci 58: 23-37.

HAN DW, SONG SJ, UHUM SJ, DO JT, KIM NH, CHUNG KS, LEE HT (2003) Expression of IGF2 and IGF receptor mRNA in bovine nuclear transferred embryos. Zygote 11: 245-252.

HANCOCK JT, DESIKAN R, NEILL SJ (2001) Role of reactive oxygen species in cell signalling pathways. Biochem Soc Trans 29:345-350.

HOLM P, BOOTH PJ, CALLESEN H (2002) Kinetics of early in vitro development of bovine in vivo- and in vitro-derived zygotes produced and/or cultured in chemically defined or serum-containing media. Reproduction 123: 553-565.

HUGENTOBLER SA, HUMPHERSON PG, LEESE HJ, SREENAN JM, MORRIS DG (2008) Energy substrates in bovine oviduct and uterine fluid and blood plasma during the oestrous cycle. Mol Reprod Dev 75: 496-503.

JANG G, HONG SG, LEE BC (2011) Cloned calves derived from somatic cell nuclear transfer embryos cultured in chemically defined medium or modified synthetic oviduct fluid. J Vet Sci 12: 83-89.

JOUNEAU A, RENARD JP (2003) Reprogramming in nuclear transfer. Curr Opin Genet Dev 13: 486-491.

KAMJOO M, BRISON DR, KIMBER SJ (2002) Apoptosis in the preimplantation mouse embryo: effect of strain difference and in vitro culture. Mol Reprod Dev 61: 67-77.

KEEFER CL (2004) Production of bioproducts through the use of transgenic animal models. Anim Reprod Sci 82-83: 5-12.

KIM HS, LEE JY, JEONG EJ, YANG CJ, HYUN SH, SHIN T, HWANG WS (2012) Effects of repetitive ionomycin treatment on in vitro development 
of bovine somatic cell nuclear transfer embryos. J Reprod Dev 58: 132139.

KOO DB, KANG YK, CHOI YH, PARK JS, KIM HN, OH KB, SON DS, PARK H, LEE KK, HAN YM (2002) Aberrant allocations of inner cell mass and trophectoderm cells in bovine nuclear transfer blastocysts. Biol Reprod 67: 487-492.

KRISHER RL, LANE M, BAVISTER BD (1999) Developmental competence and metabolism of bovine embryos cultured in semi-defined and defined culture media. Biol Reprod 60: 1345-1352.

KUBOTA C, YAMAKUCHI H, TODOROKI J, MIZOSHITA K, TABARA N, BARBER M, YANG X (2000) Six cloned calves produced from adult fibroblast cells after long-term culture. Proc Natl Acad Sci U S A 97: 990-995.

LANE M, GARDNER DK, HASLER MJ, HASLER JF (2003) Use of G1.2/G2.2 media for commercial bovine embryo culture: equivalent development and pregnancy rates compared to co-culture. Theriogenology 60: 407-419.

LEYENS G, VERHAEGHE B, LANDTMETERS M, MARCHANDISE J, KNOOPS B, DONNAY I (2004) Peroxiredoxin 6 is upregulated in bovine oocytes and cumulus cells during in vitro maturation: role of intercellular communication. Biol Reprod 71: 1646-1651.

LI E, BEARD C, JAENISCH R (1993) Role for DNA methylation in genomic imprinting. Nature 366: 362-365.

LI E, BESTOR TH, JAENISCH R (1992) Targeted mutation of the DNA methyltransferase gene results in embryonic lethality. Cell 69: 915-926.

LI Z, SUN X, CHEN J, LIU X, WISELY SM, ZHOU Q, RENARD JP, LENO GH, ENGELHARDT JF (2006) Cloned ferrets produced by somatic cell nuclear transfer. Dev Biol 293: 439-448.

LIM JM, MEI Y, CHEN B, GODKE RA, HANSEL W (1999) Development of bovine IVF oocytes cultured in medium supplemented with a nitric oxide scavenger or inhibitor in a co-culture system. Theriogenology 51: 941-949.

LIM JM, OKITSU O, OKUDA K, NIWA K (1994) Effects of fetal calf serum in culture medium on development of bovine oocytes matured and fertilized in vitro. Theriogenology 41: 1091-1098.

LIM KT, JANG G, KO KH, LEE WW, PARK HJ, KIM JJ, LEE SH, HWANG WS, LEE BC, KANG SK (2007) Improved in vitro bovine embryo development and increased efficiency in producing viable calves using defined media. Theriogenology 67: 293-302.

LIU Z, FOOTE RH (1995) Effects of amino acids on the development of invitro matured/in-vitro fertilization bovine embryos in a simple proteinfree medium. Hum Reprod 10: 2985-2991.

LIVAK KJ, SCHMITTGEN TD (2001) Analysis of relative gene expression data using real-time quantitative PCR and the 2(-Delta Delta C(T)) Method. Methods 25: 402-408.

LONERGAN P, O'KEARNEY-FLYNN M, BOLAND MP (1999) Effect of protein supplementation and presence of an antioxidant on the development of bovine zygotes in synthetic oviduct fluid medium under high or low oxygen tension. Theriogenology 51: 1565-1576.

LONERGAN P, RIZOS D, KANKA J, NEMCOVA L, MBAYE AM, KINGSTON M, WADE M, DUFFY P, BOLAND MP (2003) Temporal sensitivity of bovine embryos to culture environment after fertilization and the implications for blastocyst quality. Reproduction 126: 337-346.

MANEVICH Y, SWEITZER T, PAK JH, FEINSTEIN SI, MUZYKANTOV V, FISHER AB (2002) 1-Cys peroxiredoxin overexpression protects cells against phospholipid peroxidation-mediated membrane damage. Proc Natl Acad Sci U S A 99: 11599-11604.

MASTROMONACO GF, SEMPLE E, ROBERT C, RHO GJ, BETTS DH, KING WA (2004) Different culture media requirements of IVF and nuclear transfer bovine embryos. Reprod Domest Anim 39: 462-467.

MIYOSHI K, RZUCIDLO SJ, GIBBONS JR, ARAT S, STICE SL (2001) Development of porcine embryos reconstituted with somatic cells and enucleated metaphase I and II oocytes matured in a protein-free medium. BMC Dev Biol 1: 12.

NEDAMBALE TL, DINNYES A, GROEN W, DOBRINSKY JR, TIAN XC, YANG X (2004) Comparison on in vitro fertilized bovine embryos cultured in KSOM or SOF and cryopreserved by slow freezing or vitrification. Theriogenology 62: 437-449.

OHNO M, AOKI N, SASAKI H (2001) Allele-specific detection of nascent transcripts by fluorescence in situ hybridization reveals temporal and culture-induced changes in Igf2 imprinting during pre-implantation mouse development. Genes Cells 6: 249-259.

PAK JH, MANEVICH Y, KIM HS, FEINSTEIN SI, FISHER AB (2002) An antisense oligonucleotide to 1-cys peroxiredoxin causes lipid peroxidation and apoptosis in lung epithelial cells. J Biol Chem 277: 49927-49934.
PANARACE M, AGUERO JI, GARROTE M, JAUREGUI G, SEGOVIA A CANE L, GUTIERREZ J, MARFIL M, RIGALI F, PUGLIESE M, YOUNG S, LAGIOIA J, GARNIL C, FORTE PONTES JE, ERENO JUNIO JC, MOWER S, MEDINA M (2007) How healthy are clones and their progeny: 5 years of field experience. Theriogenology 67: 142-151.

PANDEY A, GUPTA SC, SINGH N, RANA JS, GUPTA N (2010) Efficiency of SCNT buffalo (Bubalus bubalis) embryos in different culture medium and analysis of mRNA expression of insulin-like growth factors during embryogenesis. Reprod Domest Anim 45: 786-795.

PERECIN F, MEO SC, YAMAZAKI W, FERREIRA CR, MERIGHE GK, MEIRELLES FV, GARCIA JM (2009) Imprinted gene expression in in vivo- and in vitro-produced bovine embryos and chorio-allantoic membranes. Genet Mol Res 8: 76-85.

PEURA TT, TROUNSON AO (1998) Recycling bovine embryos for nuclear transfer. Reprod Fertil Dev 10: 627-632.

PFAFFL MW (2001) A new mathematical model for relative quantification in real-time RT-PCR. Nucleic Acids Res 29: e45.

PFAFFL MW, HORGAN GW, DEMPFLE L (2002) Relative expression software tool (REST) for group-wise comparison and statistical analysis of relative expression results in real-time PCR. Nucleic Acids Res 30: e36.

PHELAN SA, WANG $X$, WALLBRANDT P, FORSMAN-SEMB K, PAIGEN B (2003) Overexpression of Prdx6 reduces H2O2 but does not prevent diet-induced atherosclerosis in the aortic root. Free Radic Biol Med 35: 1110-1120.

POLEJAEVA IA, CAMPBELL KH (2000) New advances in somatic cell nuclear transfer: application in transgenesis. Theriogenology 53: 117-126.

RIZOS D, GUTIERREZ-ADAN A, PEREZ-GARNELO S, DE LA FUENTE J, BOLAND MP, LONERGAN P (2003) Bovine embryo culture in the presence or absence of serum: implications for blastocyst development, cryotolerance, and messenger RNA expression. Biol Reprod 68: 236-243.

RIZOS D, LONERGAN P, BOLAND MP, ARROYO-GARCIA R, PINTADO B, DE LA FUENTE J, GUTIERREZ-ADAN A (2002) Analysis of differential messenger RNA expression between bovine blastocysts produced in different culture systems: implications for blastocyst quality. Biol Reprod 66: 589-595.

ROBERTSON KD, UZVOLGYI E, LIANG G, TALMADGE C, SUMEGI J GONZALES FA, JONES PA (1999) The human DNA methyltransferases (DNMTs) 1, 3a and 3b: coordinate mRNA expression in normal tissues and overexpression in tumors. Nucleic Acids Res 27: 2291-2298.

ROSENKRANS CF, JR., FIRST NL (1994) Effect of free amino acids and vitamins on cleavage and developmental rate of bovine zygotes in vitro. J Anim Sci 72: 434-437.

SHIN T, KRAEMER D, PRYOR J, LIU L, RUGILA J, HOWE L, BUCK S, MURPHY K, LYONS L, WESTHUSIN M (2002) A cat cloned by nuclear transplantation. Nature 415: 859.

SIMS M, FIRST NL (1994) Production of calves by transfer of nuclei from cultured inner cell mass cells. Proc Natl Acad Sci U S A 91: 6143-6147.

STICE SL, ROBL JM, PONCE DE LEON FA, JERRY J, GOLUEKE PG, CIBELLI JB, KANE JJ (1998) Cloning: new breakthroughs leading to commercial opportunities. Theriogenology 49: 129-138.

TAKAHASHI $\mathrm{M}$, KEICHO $\mathrm{K}$, TAKAHASHI $\mathrm{H}$, OGAWA $\mathrm{H}$, SCHULTZ RM, OKANO A (2000) Effect of oxidative stress on development and DNA damage in in-vitro cultured bovine embryos by comet assay. Theriogenology 54: 137-145.

TERVIT HR, WHITTINGHAM DG, ROWSON LE (1972) Successful culture in vitro of sheep and cattle ova. J Reprod Fertil 30: 493-497.

THOMPSON JG, ALLEN NW, MCGOWAN LT, BELL AC, LAMBERT MG, TERVIT HR (1998) Effect of delayed supplementation of fetal calf serum to culture medium on bovine embryo development in vitro and following transfer. Theriogenology 49: 1239-1249.

VAN SOOM A, YSEBAERT MT, DE KRUIF A (1997) Relationship between timing of development, morula morphology, and cell allocation to inner cell mass and trophectoderm in in vitro-produced bovine embryos. Mol Reprod Dev 47: 47-56.

VANDESOMPELE J, DE PRETER K, PATTYN F, POPPE B, VAN ROY N, DE PAEPE A, SPELEMAN F (2002) Accurate normalization of real-time quantitative RT-PCR data by geometric averaging of multiple internal control genes. Genome Biol 3: RESEARCH0034.

WAKAYAMA T, PERRY AC, ZUCCOTTI M, JOHNSON KR, YANAGIMACHI R (1998) Full-term development of mice from enucleated oocytes injected with cumulus cell nuclei. Nature 394: 369-374.

WANG S, LIU Y, HOLYOAK GR, BUNCH TD (1997) The effects of bovine serum albumin and fetal bovine serum on the development of pre- and postcleavage-stage bovine embryos cultured in modified CR2 and M199 media. Anim Reprod Sci 48: 37-45. 
WANG YS, TANG S, AN ZX, LI WZ, LIU J, QUAN FS, HUA S, ZHANG $Y$ (2011) Effect of mSOF and G1.1/G2.2 media on the developmental competence of SCNT-derived bovine embryos. Reprod Domest Anim 46: 404-409.

WELLS DN, MISICA PM, TERVIT HR (1999) Production of cloned calves following nuclear transfer with cultured adult mural granulosa cells. Biol Reprod 60: 996-1005.

WILMUT I, SCHNIEKE AE, MCWHIR J, KIND AJ, CAMPBELL KH (1997) Viable offspring derived from fetal and adult mammalian cells. Nature 385: 810-813.

WRENZYCKI C, NIEMANN H (2003) Epigenetic reprogramming in early embryonic development: effects of in-vitro production and somatic nuclear transfer. Reprod Biomed Online 7: 649-656.

WRENZYCKI C, WELLS D, HERRMANN D, MILLER A, OLIVER J, TERVIT R, NIEMANN H (2001) Nuclear transfer protocol affects messenger RNA expression patterns in cloned bovine blastocysts. Biol Reprod 65: 309-317.

XIONG XR, WANG LJ, WANG YS, HUA S, ZI XD, ZHANG Y (2012) Different preferences of IVF and SCNT bovine embryos for culture media. Zygote 1-9.
YOSHIOKA K, OTHMAN AM, TANIGUCHI T, YAMANAKA H, SEKIKAWA K (1997) Differential patterns of blastulation in bovine morulae cultured in synthetic oviduct fluid medium containing FCS or BSA. Theriogenology 48: 997-1006.

YOUNG LE, SINCLAIR KD, WILMUT I (1998) Large offspring syndrome in cattle and sheep. Rev Reprod 3: 155-163.

ZAKHARTCHENKO V, ALBERIO R, STOJKOVIC M, PRELLE K, SCHERNTHANER W, STOJKOVIC P, WENIGERKIND H, WANKE R, DUCHLER M, STEINBORN R, MUELLER M, BREM G, WOLF E (1999) Adult cloning in cattle: potential of nuclei from a permanent cell line and from primary cultures. Mol Reprod Dev 54: 264-272.

ZHANG L, HUA S, ZHANG Y, QUAN FS, LIU FJ, LIAO LR, JIANG YH (2007) [Optimization of culture measure for bovine-bovine and goatbovine cloned embryos in vitro]. Sheng Wu Gong Cheng Xue Bao 23: 662-666.

ZHOU Q, RENARD JP, LE FRIEC G, BROCHARD V, BEAUJEAN N, CHERIFI Y, FRAICHARD A, COZZI J (2003) Generation of fertile cloned rats by regulating oocyte activation. Science 302: 1179 . 